\title{
Identifying groundwater recharge zones using remote sensing \& GIS techniques in Amaravathi aquifer system, Tamil Nadu, South India
}

\author{
Mohanavelu Senthilkumar*, Devadasan Gnanasundar and Rethinam Arumugam
}

\begin{abstract}
In order to increase the sustainability of the wells and arrest the declining groundwater level trends in Amaravathi aquifer system, southern India, remote sensing and geographic information system (GIS) approach was attempted to identify favourable regions for construction of artificial recharge structures. GIS overlay analysis was carried out wherein 8 layers viz. geology, geomorphology, slope, soil, land use, post monsoon water level, weathering depth and waterbodies/drainage were integrated. Survey of India toposheet, Indian Remote Sensing Satellite IC data and ASTER data were used to develop the various thematic maps. These maps were later transferred to raster data. Groundwater level from the monitoring stations and weathering thickness data from the 248 deep wells constructed were used for the integration. Four zone namely very high, high, moderate and very poor have been demarcated. About $45 \%$ of the study area was categorised as high to very highly feasible zone. The existing artificial recharge structures in the region were also plotted and proposed artificial recharge structures were calculated. About 166 masonry check dam, 155 nala bunds, 575 recharge shafts (within tanks), 716 percolation ponds (repair, renovation and restoration) have been calculated and implementation of the proposed structures would create an additional water resource of 198 million $\mathrm{m}^{3}$ annually.
\end{abstract}

Keywords: Artificial recharge structures, GIS, Remote sensing, Overlay analysis, Groundwater

\section{Introduction}

India is the biggest user of groundwater in the world. Groundwater caters to more than $60 \%$ for agricultural activities and more than $85 \%$ for drinking water [1]. Groundwater withdrawal over the years has resulted in deepening of water levels and drying of shallow groundwater abstraction structures [2, 3]. Artificial recharge and rainwater harvesting are the possible solution to address the issues apart from demand side management [1]. The aim of the study is to demarcate the groundwater recharge zones for better management of the aquifer system located in Tamil Nadu state, South India, where the dependency on groundwater has significantly increased in recent years. This relentless groundwater withdrawal for various sectors (irrigation, domestic and

\footnotetext{
* Correspondence: msent50@yahoo.com

Central Ground Water Board, Ministry of Water Resources, River Development \& Ganga Rejuvenation, Chennai 600090, India
}

industries) has caused in lowering of groundwater levels, long-term declining trend and even drying up of wells. Various measures such as rainwater harvesting, artificial recharge and water use efficiency are successfully practiced by Central and State agencies. But for effective implementation of artificial recharge schemes, identification of appropriate location and structure is crucial. Several researchers [4-8] have applied integrated geographic information system (GIS) \& remote sensing techniques to identify potential groundwater zones. Remote sensing and GIS cover a huge \& unapproachable area of the earth surface within limited time for determining the areas of potential groundwater and for locating sites for artificial recharge. Researchers have used the geospatial expertise for groundwater studies by interpreting thematic layers such as geomorphology, geology, drainage pattern, lineament, soil, rainfall intensity and slope. Integration of these thematic layers coupled with field data such as post

(c) The Author(s). 2019 Open Access This article is distributed under the terms of the Creative Commons Attribution 4.0 International License (http://creativecommons.org/licenses/by/4.0/), which permits unrestricted use, distribution, and 
monsoon water levels and depth of weathering has not been attempted by researchers. This integrated approach can identify favourable sites for artificial recharge within the aquifer system. Therefore, the present study was carried out in Amaravathi aquifer system covering an area of $12,285 \mathrm{~km}^{2}$, wherein 8 layers viz. geology, slope, soil, geomorphology, land use/land cover, drainage \& water bodies, weathered zone and depth to groundwater level (post monsoon period) were integrated in spatial domain of GIS.

\section{Study area}

The Amaravathi aquifer system (study area) forms a part of Cauvery basin and lies between north latitude $10^{\circ} 14^{\prime}$ $00^{\prime \prime}$ to $11^{\circ} 16^{\prime} 00^{\prime \prime}$ and east longitude $76^{\circ} 45^{\prime} 00^{\prime \prime}$ to $78^{\circ} 15^{\prime}$ 00". The aquifer system covers an area of $12,285 \mathrm{~km}^{2}$ covering parts of five districts viz., Coimbatore, Tiruppur, Erode, Dindigul and Karur districts (Fig. 1) and is administratively governed by 115 firkas or revenue villages The average rainfall is $720 \mathrm{~mm}$, with about $40 \%$ of the precipitation contributed by south-west monsoon and 50 to $60 \%$ by northeast monsoon $[9,10]$. Amaravathi and Noyil are the major rivers with Chinnar, Kodavanar, Nanganji, Kuduraiyar and Shanmuganadi their tributaries. The flow in these rivers and tributaries are limited to maximum of 10 to $15 \mathrm{~d}$ during the monsoon period. The requirements for irrigation and domestic usage are met by groundwater resources as surface water resources are very limited. The total annual replenishable groundwater resources of the study area is about 1475.11 million $\mathrm{m}^{3}(\mathrm{mcm})$. The study area experiences frequent droughts resulting in over dependency on groundwater resources. Already the 74 groundwater assessment units have been categorised as over exploited and critical out of the total of 107 units [2]. As per latest groundwater resources estimation, the groundwater withdrawal in 74 units is more than the annual groundwater recharge [11]. This has resulted in declining groundwater levels and decrease in sustainability of wells.

\section{Methodology}

The identification of groundwater potential zone as well as identification of locations for artificial recharge structures within the Amaravathi aquifer system was carried out by integrating satellite derived various thematic maps in GIS platform. In the present study, the following layers were prepared and used for identification of favourable recharge areas. All the layers were generated in 1:50000 scale. Drainage layer was generated from survey of India toposheet.

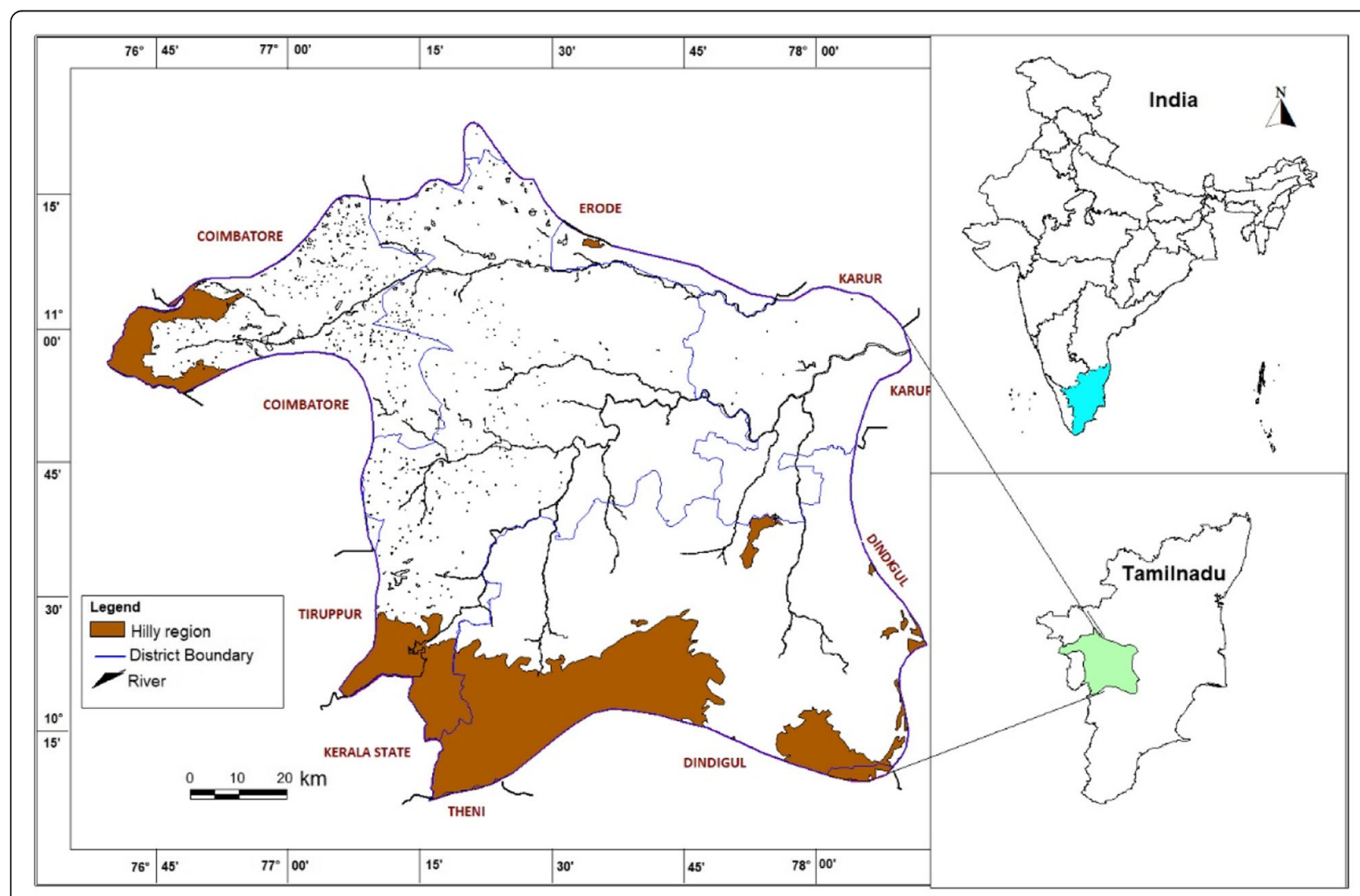

Fig. 1 Location of the study area 
The ASTER $30 \mathrm{~m}$ was downloaded and 60,000 points were extracted using ArcGIS and slope map was generated. Further percentage of slope map was prepared. The soil map was obtained from National Bureau of soil survey and land use planning. Raster map was digitised and vector map for analysis was generated. Thematic map geomorphology and land use/land cover (LULC) were obtained from Institute of Remote Sensing, Chennai. These were processed from high resolution satellite data IRS (Indian Remote-Sensing) P6 - LISS (Linear Imaging Self-Scanning) III and validated through field verification. Geology map was obtained from Geological Survey of India. All these data were geo-rectified and projected in Geographic coordinate system - World Geodetic System 1984 with Universal Transverse Mercator (UTM) Zone $44 \mathrm{~N}$ for smooth usage in the GIS environments. The methodology adopted for this study is presented in flow chart in Fig. 2. From field survey, the weathering depth and post monsoon water levels were obtained from 416 monitoring wells and 248 borewell data [12]. The favourable location for groundwater recharge is greatly influenced by geology, geomorphology, LULC, slope, soil, drainage/water bodies, post monsoon water level and weathered thickness \& fractures occurring at near surface [13]. To identify suitable zone for groundwater recharge, spatial data integration using index overlay model in GIS environ was carried out. In this model, seven layers were integrated by assigning weightage for the theme with scale of 1-100 and sub-classes of the theme between 1 to 4 scales. The resultant map was reclassified into four classes viz. very high, high, moderate and poor categories.

\section{Results and discussion Geomorphology}

Geomorphologically, the study area consists of hills and plain landforms (Fig. 3a). Hill landforms like residual hills, denudation and structural hills act as runoff zone. In the plain landforms, pediplain that influences groundwater recharge occupies a large portion. A series of hills exist within the study area and are covered by reserved forests. The major geomorphological units with its $\%$ of coverage area are shown in Fig. 4. The southern part of the basin is covered with series of hill ranges of Kodaikanal and form upland. Many lower order streams flowing from this upland region join in Chinnar river. Pediments form on northern and eastern parts of the basin. More than $90 \%$ of the area is occupied by upland and pediment zones. Structural, residual hills and pediplains are the other geomorphic features manifested in lower proportion (Fig. 3a). The ranks were allotted to the individual landforms, according to its respective features influencing the groundwater recharge, holding and its occurrence (Table 1).

\section{Land use and soil}

The land use (Fig. 3b) and soil provides information on infiltration, soil moisture and vegetation. Remote sensing

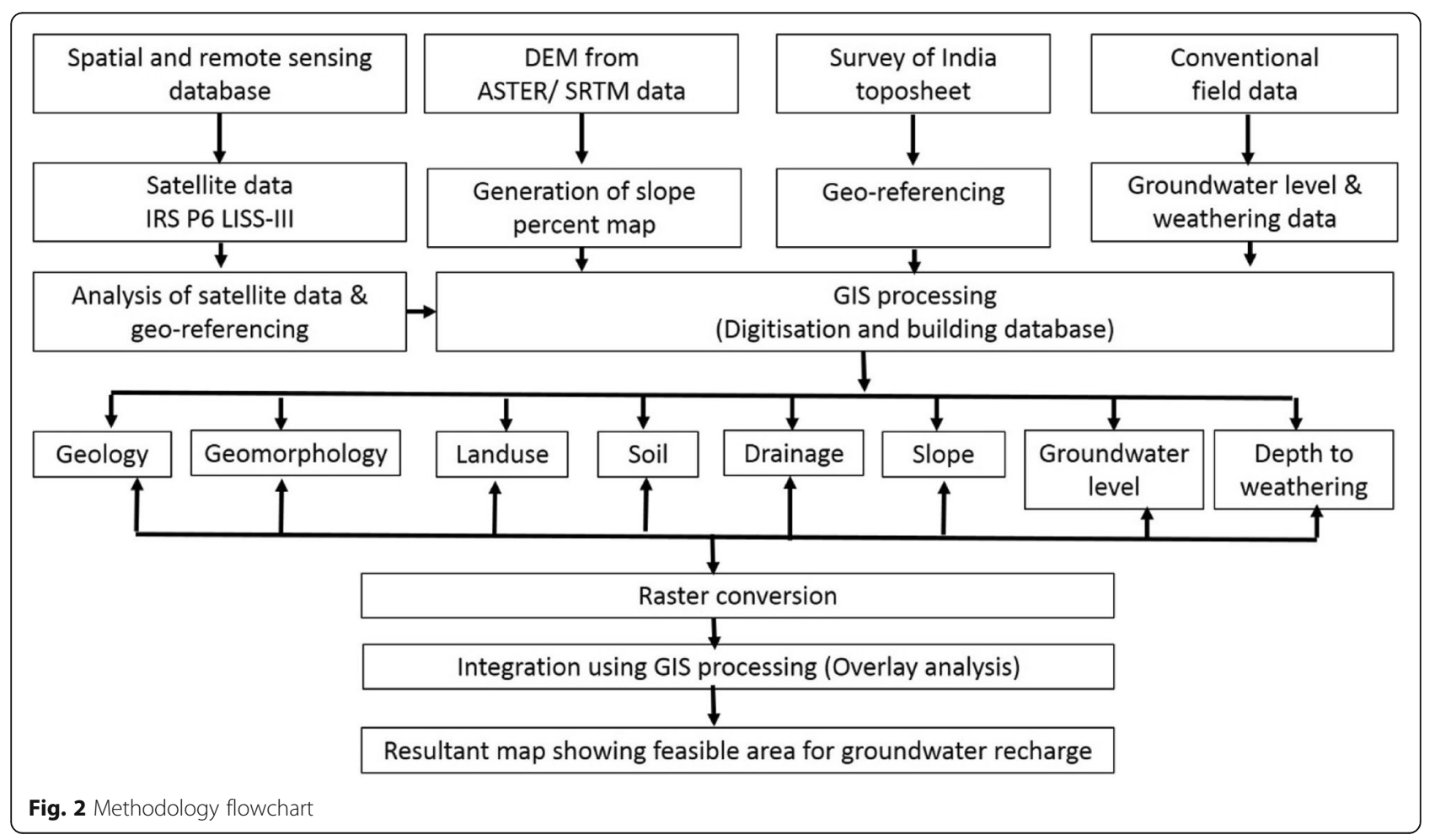



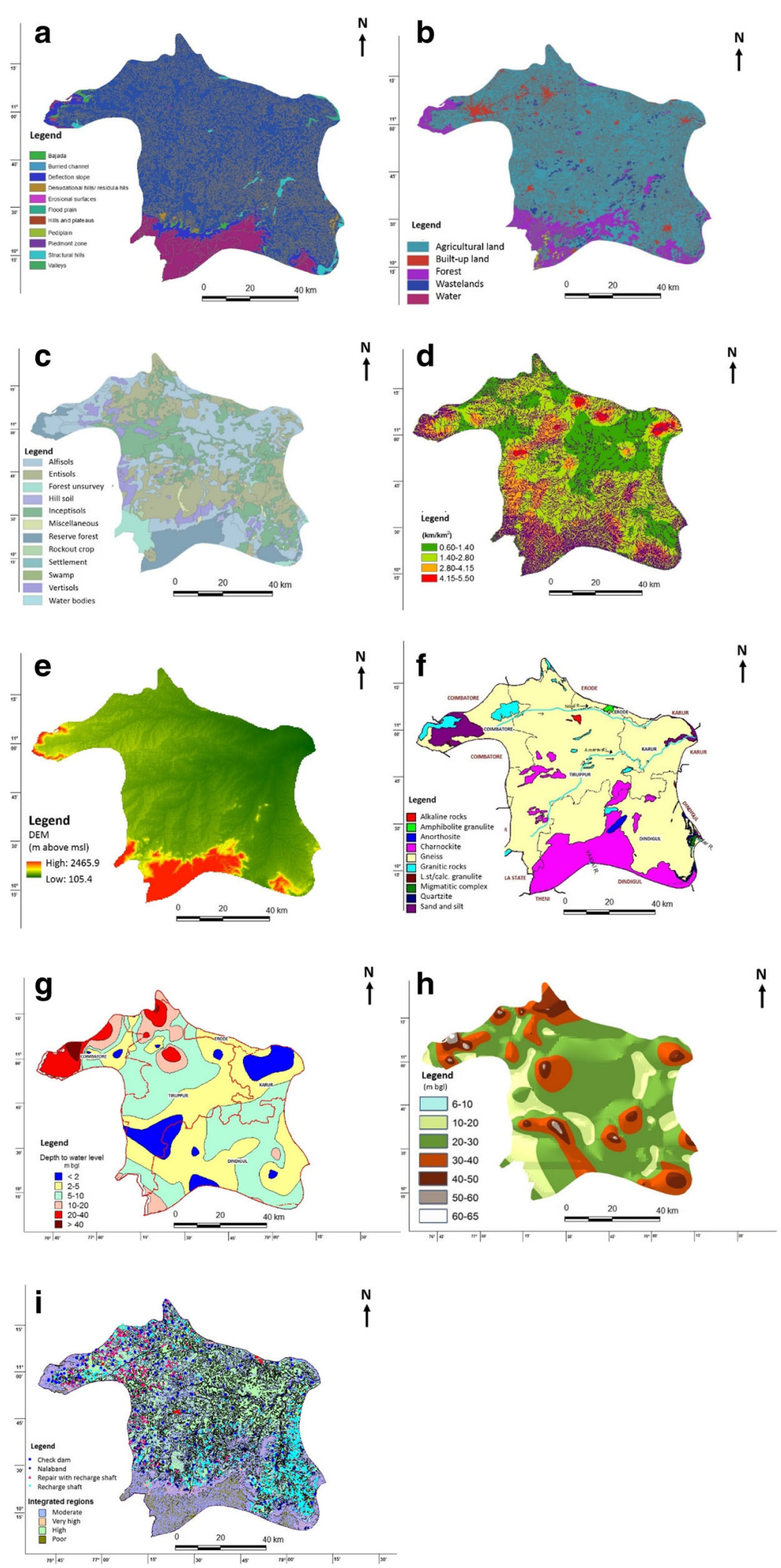

Fig. 3 Amaravathi aquifer system. (a) Geomorphological map, (b) Land use/land cover map, (c) Soil cover map, (d) Drainage map, (e) Elevation map, (f) Geology, (g) Post Monsoon water level map, (h) Depth to Weathering map, (i) Groundwater management plan 


\section{GEOMORPHOLOGY}

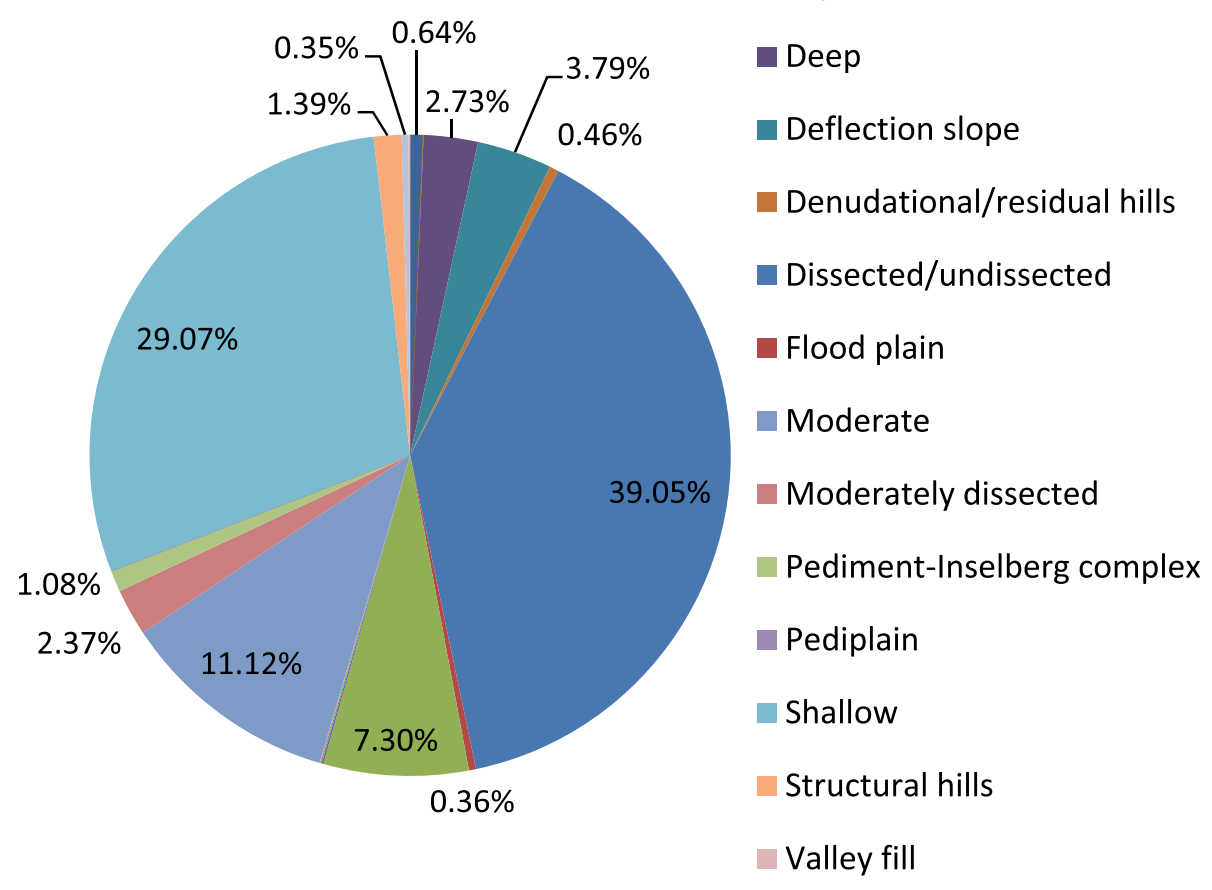

Bajada

Pediment-Inselberg complex

Pediplain

Shallow

Structural hills

Valley fill

Fig. 4 Geomorphology classification - Level 3

and GIS offer dependable and more precise baseline information for LULC mapping. Landsat \& Operational Land Imager images of 2014 were used for Land use land cover mapping (Fig. 3b). Predominantly the area is characterised by the wet crop (water intensive crops like paddy, sugarcane \& banana), plantation and dry crop (agricultural field) (Fig. 5) and accounts for $80 \%$ of the total area of the aquifer system. This area is highly suitable for water conservation and recharge. The ranks were devised to the individual LULC type, according to its individual features influencing the groundwater recharge, holding and its occurrence (Table 1). The soil (Fig. 3c) is mainly of alfisols type, which covers more than $60 \%$ of the study area. The ranks were formulated to the respective soil types, according to its respective features influencing the groundwater recharge, holding and its occurrence (Table 1).

\section{Drainage and water bodies}

Rainfed ponds/tanks and surface water bodies are spread over the entire study area. Canals (irrigation purpose) flows through the southern part of the area. The drainage pattern is the dendritic and sub-dendritic (Fig. 3d). Individual network of drainage was extracted and delineated from Cartosat Digital Elevation Model (DEM) with the assistance of Arc Hydro tool of ArcGIS. Extracted drainage networks were overlaid on the digitised stream of the Survey of India Toposheet for cross validation.
The drainage density map was prepared using the line density analysis tool. The drainage density is indirectly connected to the soil infiltration capacity and weight, which is assigned low density and vice versa (Fig. 3d).

\section{Slope}

The slope of any terrain plays a vital role in allowing the infiltration of water into the subsurface system [14]. In regions of gentle slope, the runoff will be slow and will have more time for percolation of rainwater, whereas near vertical slope facilities high runoff which has limited residence period for rainwater to infiltrate. The slope map of study area was prepared from the Cartosat DEM of $30 \mathrm{~m}$ spatial resolution and was classified into 5 classes, i.e., nearly levelled/no slope $(<3 \%)$, gentle slope (3-5\%), moderate $(5-10 \%)$, moderate to steep $(10-15 \%)$ and very steep (>15\%) (Fig. 3e). The ranks were assigned to the respective slope class, according to its respective features influencing the groundwater recharge, holding and its occurrence (Table 1).

\section{Geohydrology}

The entire aquifer system is underlain by the crystalline metamorphic gneiss complex consisting of HornbledeBiotite gneiss, Epidote-Hornblede gneiss and Magnesite Quartzites. Groundwater occurs within the weathered and fractured gneiss rocks under phreatic condition. (Fig. 3f). The thickness of the weathering is extremely 
Table 1 Theme wise features, ranking \& weightage

\begin{tabular}{|c|c|c|c|c|}
\hline Theme & Features & Rank (in words) & Rank (in number) & Weightage \\
\hline \multirow[t]{6}{*}{ Geomorphology } & Pediments-moderate & Moderate & 2 & \multirow[t]{6}{*}{15} \\
\hline & Pediments-deep & Moderate & 2 & \\
\hline & Pediment-shallow & Low & 1 & \\
\hline & Dissected plateaus & Very low & 1 & \\
\hline & Valley fills & High & 3 & \\
\hline & Bazada zone & High & 3 & \\
\hline \multirow[t]{8}{*}{ Landuse/Landcover } & Settlements & Low & 1 & \multirow[t]{8}{*}{10} \\
\hline & Barren land/rocky & Low & 1 & \\
\hline & Fallow land & Moderate & 2 & \\
\hline & Water body & High & 3 & \\
\hline & Plantation & High & 3 & \\
\hline & Forest & Moderate & 2 & \\
\hline & Vegetation & Moderate & 2 & \\
\hline & Wet lands & High & 3 & \\
\hline \multirow[t]{6}{*}{ Soil } & Clayey soil/loam & Low & 1 & \multirow[t]{6}{*}{10} \\
\hline & Silty soil & Low & 1 & \\
\hline & Red soil & Moderate & 2 & \\
\hline & Lateritic soil & Moderate & 2 & \\
\hline & Gravely soil & High & 3 & \\
\hline & Sandy loam & High & 3 & \\
\hline \multirow[t]{5}{*}{ Slope (\%) } & $<3$ & Nearly levelled/Nery gentle & 3 & \multirow[t]{5}{*}{15} \\
\hline & 3 to 5 & Gently sloping & 3 & \\
\hline & 5 to10 & Moderate & 2 & \\
\hline & 10 to 15 & Moderate to steep & 2 & \\
\hline & $>15$ & Very steep & 1 & \\
\hline \multirow[t]{4}{*}{ Post monsoon groundwater level } & $<3 \mathrm{~m} \mathrm{bgl}$ & No space - low & 1 & \multirow[t]{4}{*}{15} \\
\hline & $>3 \&<6 \mathrm{~m} \mathrm{bgl}$ & Moderate & 2 & \\
\hline & $>6 \&<9 \mathrm{~m} \mathrm{bgl}$ & High & 3 & \\
\hline & $>9 \mathrm{~m} \mathrm{bgl}$ & Very high & 3 & \\
\hline \multirow[t]{5}{*}{ Geology } & Charnockite & Low & 1 & \multirow[t]{5}{*}{10} \\
\hline & Granitic gneiss & Low & 1 & \\
\hline & Banded gneissic complex/Banded migmatite & Low & 1 & \\
\hline & Highly weathered granitic gneiss & Moderate & 2 & \\
\hline & Alluvium & High & 3 & \\
\hline \multirow[t]{2}{*}{ Drainage } & Other regions & Low & 1 & \multirow[t]{2}{*}{10} \\
\hline & Drainage lines & High & 3 & \\
\hline \multirow[t]{4}{*}{ Weathering } & $>6$ & Low & 1 & \multirow[t]{4}{*}{15} \\
\hline & $6-10$ & Moderate & 2 & \\
\hline & $10-20$ & High & 3 & \\
\hline & $>20 \mathrm{~m}$ & Very high & 3 & \\
\hline
\end{tabular}

bgl - below ground level

variable and the depths of groundwater withdrawal structures are directly related to the intensity of weathering and occurrence of fractures. Large diameter dug well is more common groundwater abstraction structures and their diameter ranges between 3 and $10 \mathrm{~m}$. The depths of the dug wells range between 6 and $18 \mathrm{~m}$ below 

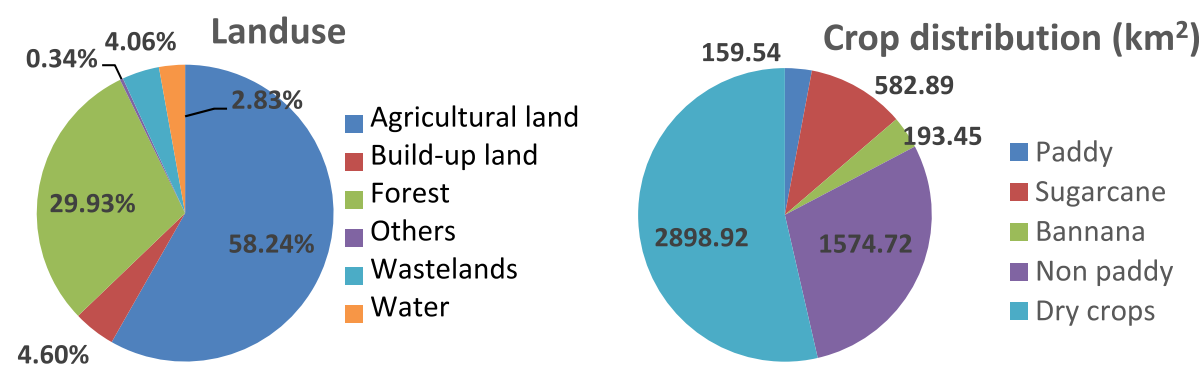

Fig. 5 Level 1 Landuse distribution \& cropping pattern of the Amaravathi aquifer system

ground level (bgl). The yield of the dug wells is less than $1 \mathrm{~L} \mathrm{~s}^{-1}$ in summer months and few wells becomes dry. The yield is adequate for irrigating for one or two crops in monsoon period. Five major rock type have been demarcated and ranked into three groups viz., hard rocks, weathered formation and alluvium. The ranks were devised to the respective rock types, according to its individual features influencing the groundwater recharge, groundwater holding and its occurrence.

The depth of wells varies from 6.6 to $27 \mathrm{~m}$ bgl. The present water levels in the aquifer system is in the range of 1.7 to $14.9 \mathrm{~m}$ bgl during pre- monsoon (May 2015) and from 1.0 to $20.1 \mathrm{~m}$ bgl during post monsoon (January 2016) (Fig. 3g) [2, 12]. Decadal mean of groundwater level for periods before and after monsoon was also prepared to understand the average groundwater level changes. Before the onset of the monsoon, the majority of the regions is less than $6 \mathrm{~m} \mathrm{bgl}$ whereas groundwater levels after the monsoon is less than $5 \mathrm{~m} \mathrm{bgl} \mathrm{in} \mathrm{most} \mathrm{parts.}$

\section{Rainfall}

The study area experiences sub-tropical climate with high temperature during March to May. The mean temperature of the study area ranges from 19 to $35^{\circ} \mathrm{C}$ with humidity as high as $70 \%$. The wind speed is generally high during the months of July and August, ranging from 7.4 to $12.6 \mathrm{~km} \mathrm{~h}^{-1}$. The study area receives rainfall during the months of June to September (southwest monsoon) and October to December (northeast monsoon). Summer rains during January to May have also been recorded. The area receives the major rainfall from northeast monsoon. Heavy rainfall occurs due to low pressure depressions. The normal annual rainfall is 720 mm with monsoon rainfall (June to December) $560 \mathrm{~mm}$ and summer rainfall (January to May) $160 \mathrm{~mm}$ [2].

\section{Weathering}

Borehole lithologs of the wells (total 248) constructed by central and state groundwater department were collected and analysed. The depth of these groundwater abstraction wells ranged from 60 to $200 \mathrm{~m}$ bgl. Based on the litholog analysis, the depth to weathering map was prepared (Fig. 3h). Three-rank zones (low, moderate and high) have been demarcated based on the depth of weathering.

\section{Overlay analysis}

Overlay analysis is a multi-criterion study wherein investigation is carried out with multifaceted things for determining certain themes with the aid of assigning rank to the respective features and then assign weightage to the respective features depending upon the weightage of the theme on the objective. In this model, seven layers were integrated by assigning weightage for the theme having scale of 1-100 and ranks of the features between 1 to 10 scales [7, 14, 15]. The ranks and weightage of parameter are given in Table 1. The resultant map has been reclassified into four classes (very high, high, moderate and poor categories of the integrated values) indicating the suitable area for artificial recharge (Table 2). Overlay analysis was carried out for individual firkas (total 115) in the GIS environment using ArcGIS software 10.4 so as to have better control over the layers and at a larger scale.

Table 2 Resultant output showing percentage of zone wise area of coverage

\begin{tabular}{lll}
\hline Zone & $\%$ of Area coverage & Suitable structures \\
\hline Very high & 10 & Suitable for all recharge structures like percolation pond and stop dam, check dam, etc. \\
High & 35 & Suitable for all recharge structures like stop dam, check dam, etc. \\
Moderate & 40 & Suitable for all recharge structures like earthen check dam, boulder check dam and nala bund, etc. \\
Poor & 15 & Hilly/Forest/Catchment area - not suitable \\
\hline
\end{tabular}


Availability of surplus surface water for artificial recharge or conservation

The annual uncommitted surface flow for Amaravathi aquifer system region was estimated as 899 million $\mathrm{m}^{3}$. Based on the available surplus surface water and hydrogeological condition, the following measures are recommended (Table 3).

\section{Artificial recharge structures and revival, repair of water bodies}

The artificial recharge structures that exist within the study area were geo-tagged. Based on the availability of space and unutilised surplus water, an additional 166 masonry check dam and 155 of nala bunds can be constructed in moderate to high recharge potential zones (Fig. 3i). The existing ponds and tanks have lost their storage capacity and the natural groundwater infiltration from these water bodies has become negligible due to siltation and encroachment by farmers for agriculture purposes. There are several such villages where ponds/ tanks are in dilapidated condition. These existing village tanks which have high siltation and damaged can be repaired/modified to serve as recharge structure (percolation tanks). Desilting coupled with provision of proper waste weirs will convert the village ponds/tanks into recharge structure. Several such types of village ponds/ tanks are available in the study area, which can be converted for augmenting groundwater recharge. About 1851 structures are available in the study area of which 220 tanks have been identified for repair and revival. About 575 tanks/water bodies have been identified wherein 716 recharge shafts need to be constructed so as to harness the surplus water (Table 3). Thus total 54.4 million $\mathrm{m}^{3}$ of runoff can be harvested by revival of ponds/tanks with recharge shafts.

\section{Water conservation measure through recharge pond}

A recharge pond is a huge dug out in the earth, usually square/rectangular in dimension, which collects rainwater and stores it for future use. It has only one inlet to control inflow and an outlet channel for discharging surplus water. The recharge ponds are bounded by earthen bunds, which control erosion on the sides of the recharge pond. The size and depth of the recharge pond are directly proportional to the size of land holding, the type of soil, water requirements, affordability of the excavation, and the possible usage or disposal of the excavated material. Water from the farm pond is conveyed to the fields either manually or by pumping.

\section{Micro irrigation system (sprinkler/drip/high-density polyethylene (HDPE) pipes)}

Micro irrigation is method of application of little and in frequent quantities of water in the soil surface (above \& below); in the form of distinct drops, constant drops or tiny streams through the emitters provided with the water delivery tubes. In flood/furrow irrigation method more than $50 \%$ of applied water is wasted through seepage to deeper level, localized inundation causes loss through evaporation and it leaches out the nutrients from the plant. Through drip \& sprinkler irrigation, wastage of irrigational water could be minimized and irrigation water is saved drastically. The conveyance losses (mainly seepage \& evaporation) can be saved up to 25 to $40 \%$ through utilization of HDPE pipes. Initially the scheme is proposed to be implemented in the worst affected areas showing deepest water levels and significant declining trends.

The total amount for recharge in unsaturated area up to the depth of $3 \mathrm{~m} \mathrm{bgl}$ is 918 million $\mathrm{m}^{3}$ and the uncommitted surplus runoff calculated to be 899 million $\mathrm{m}^{3}$. The total expense for construction of the proposed artificial recharge and water conservation structures was determined based on the master plan for groundwater recharge for Tamilnadu. The estimated costs for the proposed structure are 0.6 million USD. The expected recharge after construction of the proposed structures is about 198 million $\mathrm{m}^{3}$. These additional resources shall arrest further decline in groundwater levels and can increase the sustainability of the abstraction sturctures. An additional irrigated area of $340 \mathrm{~km}^{2}$ can be created for cultivation of dry crop like vegetable, groundnuts and pulses.

\section{Conclusions}

Geospatial technology has the advantage of covering vast regions of spatial, spectral and temporal availability of Earth surface. It covers inaccessible areas too within short time for identification of favourable zones for artificial recharge. Geospatial technology was applied in Amaravathi aquifer system covering an area $12,285 \mathrm{~km}^{2}$

Table 3 Proposed types and number of artificial recharge structures to be constructed

\begin{tabular}{llll}
\hline SI. No & Water conservation measures & Type of the structure & Number of structures \\
\hline 1 & Artificial recharge structures proposed & Masonry check dam & 166 \\
& Nala bund & Recharge shafts (in 575tanks) & 155 \\
& & Repair, renovate \& restoration of ponds (1851) & 220 \\
& & Recharge ponds of dimension: $2 \times 2 \times 2 \mathrm{~m}$ & 25,240 \\
\hline
\end{tabular}


for identification of artificial recharge structures by interpreting eight thematic layers. Integration of geomorphology, geology, drainage/water bodies, LULC, soil, and slope coupled with field data post monsoon water levels \& weathering was useful in locating sites for artificial recharge within the study area. Resultant map shows four categories (very high, high, moderate and poor regions) for locating artificial recharge structures. The north western and south eastern portions are more suitable for groundwater recharge. About $45 \%$ of the study area has very high and high regions for locating artificial recharge structures and $40 \%$ falls in the moderate zone category. Based on the availability of space and unutilised \& uncommitted surplus water, it is proposed to construct 166 masonry check dam, 155 nala bunds, 575 recharge shafts (within tanks), and 716 percolation ponds (repair, renovation and restoration). This shall create an additional groundwater resources of $198 \mathrm{mil}-$ lion $\mathrm{m}^{3}$ annually. Thus construction of these structures at various locations identified shall rejuvenate the Amaravathi aquifer system and increase the sustainability of the groundwater abstraction structures.

\section{Acknowledgements}

The authors wish to place on record their special thanks and gratitude to The Chairman, Central Ground Water Board (CGWB), Ministry of Water Resources, River Development and Ganga Rejuvenation, Government of India and all the Members of CGWB. Authors are thankfull to the Regional Director, SECR, CGWB for his inspiring guidance and support. Special thanks are due to Sh. M. Panneer, Hydrogeologist, CGWB, Dr. K. Rajarajan, Hydrogeologist and to all officers \& officials of CGWB, SECR, Chennai for their support. Help rendered by Sh. Dhanamadhavan, Geologist, Highways department is highly acknowledged.

\section{Authors' contributions}

All authors read and approved the final manuscript.

\section{Competing interests}

The authors declare that they have no competing interests.

\section{Publisher's Note}

Springer Nature remains neutral with regard to jurisdictional claims in published maps and institutional affiliations.

Received: 12 August 2018 Accepted: 3 April 2019

Published online: 29 April 2019

\section{References}

1. TWB. Deep Wells and Prudence: Towards Pragmatic Action for Addressing Groundwater Overexploitation in India. Washington, DC: The World Bank; 2010.

2. CGWB. Aquifer Mapping and Ground Water Management. Chennai: Central Ground Water Board; 2015

3. CGWB. Ground Water Scenario in India. Faridabad: Central Ground Water Board; 2016.

4. Sener E, Davraz A, Ozcelik M. An integration of GIS and remote sensing in groundwater investigations: a case study in Burdur, Turkey. Hydrogeol J. 2005;13:826-34.

5. Prasad RK, Mondal NC, Banerjee P, Nandakumar MV, Singh VS. Deciphering potential groundwater zone in hard rock through the application of GIS. Environ Geol. 2008:55:467-75.

6. Sander P, Chesley MM, Minor TB. Groundwater assessment using remote sensing and GIS in a rural groundwater project in Ghana: lessons learned. Hydrogeol J. 1996;4:40-9.
7. Suganthi S, Elango L, Subramanian SK. Groundwater potential zonation by remote sensing and GIS techniques and its relation to the groundwater level in the coastal part of the Arani and Koratalai river basin, southern India. Earth Sci Res J. 2013;17:87-95.

8. Samadder RK, Kumar S, Gupta RP. Paleochannels and their potential for artificial groundwater recharge in the western ganga plains. J Hydrol. 2011; 400:154-64

9. Rathod IM, Aruchamy S. Spatial analysis of rainfall variation in Coimbatore district Tamil Nadu using GIS. Int I Geomat Geosci. 2010;1:106-18.

10. Sukumar S, Devadass CSC, Brema J. Rainfall distribution and variability in Coimbatore district, Tamil Nadu using GIS technique. Int J Earth Sci Eng. 2016;9:596-603.

11. CGWB. Dynamic Ground Water Resources of India. Faridabad: Central Ground Water Board; 2017.

12. Sreenivas A. Aquifer Mapping of 58F/15 Toposheet Area Comprising of Parts Of Dindigul District, Tamil Nadu. Chennai: Central Ground Water Board; 2014

13. Preeja KR, Joseph S, Thomas J, Vijith H. Identification of groundwater potential zones of a tropical river basin (Kerala, India) using remote sensing and GIS techniques. J Indian Soc Remote. 2011:39:83-94.

14. Patil SG, Mohite NM. Identification of groundwater recharge potential zones for a watershed using remote sensing and GIS. Int I Geomat Geosci. 2014;4: $485-98$.

15. Kamaraj R, Gunalan N, Krishnan M, Krishnamurthy RR. Role of remote sensing and GIS in finding suitable artificial recharge zones in and around Neyveli basin, Cuddalore district, Tamil Nadu, India. J Acad Ind Res. 2014;3 295-300.

\section{Ready to submit your research? Choose BMC and benefit from:}

- fast, convenient online submission

- thorough peer review by experienced researchers in your field

- rapid publication on acceptance

- support for research data, including large and complex data types

- gold Open Access which fosters wider collaboration and increased citations

- maximum visibility for your research: over $100 \mathrm{M}$ website views per year

At BMC, research is always in progress.

Learn more biomedcentral.com/submissions 